\title{
Article
}

\section{The City within the City: A Glimpse of Elite Formation in Deptford, London and Dadaocheng, Taipei}

\author{
Alsford, Niki Joseph paul \\ Available at http://clok.uclan.ac.uk/29540/ \\ Alsford, Niki Joseph paul ORCID: 0000-0003-1939-4313 (2019) The City within \\ the City: A Glimpse of Elite Formation in Deptford, London and Dadaocheng, \\ Taipei. Journal of Urban History, 47 (1). ISSN 0096-1442
}

It is advisable to refer to the publisher's version if you intend to cite from the work. http://dx.doi.org/10.1177/0096144219868815

For more information about UCLan's research in this area go to http://www.uclan.ac.uk/researchgroups/ and search for <name of research Group>.

For information about Research generally at UCLan please go to http://www.uclan.ac.uk/research/

All outputs in CLoK are protected by Intellectual Property Rights law, including Copyright law. Copyright, IPR and Moral Rights for the works on this site are retained by the individual authors and/or other copyright owners. Terms and conditions for use of this material are defined in the policies page.

\section{CLoK}

Central Lancashire online Knowledge www.clok.uclan.ac.uk

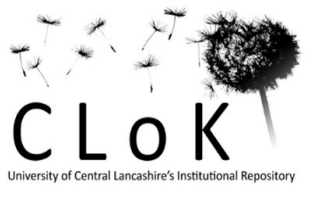


The inertia of tradition; the 'it's done this way because it's always been done this way,' coupled with the almost random decision-making by individuals and collective groups, is shrewdly interwoven into the fabric of expanding towns. The neighbourhoods in the two case studies presented in this paper have both historically avoided becoming part of the cities to which they now belong. Today they both struggle retain a sense identity that distinguishes them from the larger city. Gentrification is slowly creeping in. Deptford, often touted as 'the new Shoreditch', is popular among artists, students, and young city workers. ${ }^{1}$ Dadaocheng is similar. It is undergoing a revival with a number of artisan coffee shops and bakeries as well as art galleries and speciality retailers. ${ }^{2}$ Both locations give the impression of colourful development while maintaining historical perseveration. Yet, not all residents agree. Deptford has prided itself on its mixed-ethnic background and working class roots. Many see its development as a destruction of the social fabric of the area. ${ }^{3}$ For Dadaocheng, it is the rising business rents that have accompanied these new retailers that ire the local residents. ${ }^{4}$ Yet this kind of fervent vigour is not new in either location. Historically, both places have not only mapped and remapped their modern satellite cities, but they have a quality that has been mirrored across other cityscapes around the world. The social construction of districts is common throughout the world. No city is a homogenous block of urban development. They grow organically via a collective desire to shape a modern urban space that could meet the aspirations of its peoples; a place where the neighbourhood resided, worked, and took leisure on infrastructure that was purposely built: the scape. With its 'streets and sidewalks, its public space, the ebb and flow of its crowd, its infrastructure of transportation - the neighbourhood served as the setting for dynamic encounters and experiences. ${ }^{5}$ The dwellers within were both globally situated and 1 | Page 
connected. They were, as Prakash argues: 'thick with specific experiences, practices, imaginations, and memories. ${ }^{6}$ They were connected not only to their interurban linkages, but formed part of a transnational phenomenon of urban modern living. A modernity by which they self-defined and interpreted; one that was differentiated across a wide range of institutions - family life, economic and political structures, education, mass communication, and individual orientation. These structures - or arenas, as I shall refer to them-are understood as a narrative of continual design and redesign. Yet this (re)design was not necessarily a universal aspiration. Instead, this cultural programming in both Deptford (in South East London) and Dadaocheng (in northern Taiwan) were essentially marshalled by a rising new urban middle class. The fortunes that they acquired were contoured by their connections to the town that they helped to mould and transform.

This paper contextualizes a transnational urban phenomenon in two disconnected port towns using Michael Wood's elite-formation model, and in so doing it will argue that if the social, economic, and political factors across distinct urban spaces are comparable, then the emerging middle class will respond and behave in similar fashions. ${ }^{7}$ Upon inspection, both sites are visually similar in terms of architecture and road layout, as was the method by which individual businesses developed in each. What is more, the production of elite identity was heavily entrenched in working-class areas. The same people in the 1950s would have left and moved to suburban areas. ${ }^{8}$ Perhaps the most compelling comparison to be made in both locations - and one that justifies their comparison - is that the formation of identity shifted from one that is national to one that is heavily localized; a neighbourhood identity. A neighbourhood of which its members were (and arguably to a certain extent still are) very protective, particularly when it comes to change that they did not initiate. 


\section{THE BUILDING OF A PORT-TOWN}

[T]hough its streets are so much alike as to be a cause of considerable bewilderment to country strangers; - I do maintain, that, seen from the landward, it has its attraction as a landscape, even if we cast out of the account the noble river emptying its waters into the sea, which forms such a prominent feature in the background. ${ }^{9}$

The above quote, from Chorley's sketch of Liverpool, could have easily been in reference to either of the case studies. The consanguinity of the town to the waterway is consistent with the place being economically defined as a settlement of inhabitants whose livelihood is based on trade and commerce as opposed to agriculture. ${ }^{10}$ The versatility of which meant that the exchange of goods was both regular rather than occasional, and diverse rather than alike. Its utility intrinsically linked urban growth with migration. In both studies, this system brought about new definitions of the individual and of society as a whole. Whether this migration was internal or external, where and how they came to settle was important in the methods in which they integrated into the local labour market. What is more, especially in the case of Dadaocheng, they had an enormous impact on the ethnic balance within specific quarters of its neighbouring towns. Understanding this has important ramifications for a more integrated study on the dynamism of governance and of non-state elite power in both locations.

A central role in their similarities perhaps lies in their management of long-distance trade and commerce. To be more specific, changes in their respective arenas were intrinsically tied to the emergence of economic structures that they were all part of. In the context of this paper, this is important for two reasons: (1) Long-distance trade and commerce were not always initiated at the local level, in either location. Instead, they were actualised by State actors, such as trade boards, custom agencies, and colonial officials, governors and consuls. (2) The people that 
stimulated localism in these locations were able to demonstrate agency as emerging middleclass communities and neighbourhoods through processes of relationalism. By this, I mean, that through an expression of values and by reinforcing these upon the other classes with whom they shared space, they were able to shape relationships and influence how the neighbourhood looked and functioned.

Yet one may argue that producing a like-with-like reduces the study to what Marcel Detienne disdainfully calls 'comparer l'incomparable.' ${ }^{11}$ Yet, the differences can easily be discerned-London was a centre: a metropole - a subject of colonial expansion, whereas Taiwan was subjected to colonial expansion. Thus, a principal motivation for Deptford as a suitable comparison was made on the consideration that both locations (playing pivotal roles in the development of that larger city that they were appendaged to) historically remained in a kind of obscurity. Out of this shadow, both, more than most, owe their very existence to the river-course that flows alongside them. ${ }^{12}$ The heart of Deptford (affectionately known as the Quaggy) lies in fact on the junction of two rivers (the Thames and the Earl's Sluice - the latter being a lost river). ${ }^{13}$ Dadaocheng in comparison lies just north of the point at which the River Tamsui meets the Xindian River (the former is known as the River Dahan immediately south of this confluence).

This said, although southeast London has been proposed as a comparative for the study of urban development in northern Taiwan, it is important to note that alternatives could have easily been made elsewhere. Good examples could perhaps have been made on port locations in Southeast Asia: Padang, Manila, Haiphong, to name a few. An even more rigorous comparison could perhaps have been made in places such as St. Louis in the US state of Missouri. A comparison here could have been made on a number of factors. First in their 
colonial context, both were founded and established (St. Louis 1764) (Dadaocheng 1709) on land settled by native indigenous communities (Osage and Illiniwek peoples in St. Louis and the Ketagalan in Dadaocheng). Following the Louisiana Purchase in 1803, and the opening of the River Tamsui in 1862, both became major river ports, and with the arrival of steam shipping in the nineteenth century, a connection was made in both to other, larger commercial centres (New Orleans for the former, and Amoy, Hong Kong, Kobe and Yokohama for the latter). Types of trade and commerce followed suit, namely in the form of transportation of raw materials. Other conceivable port locations are harbours along the Euphrates and the Tigris, and perhaps to a greater extent a comparison could be made on the port city of İzmir (on the westernmost extremity of Anatolia). The diversified economic activities in both locations gave rise to a considerable variety of artisans throughout the late nineteenth century, which was supplemented by commercially orientated agrarian production in which smallholding farmers were able to export internationally and trade domestically. ${ }^{14}$ İzmir, like Dadaocheng, developed as a port town with interconnected trading relations; the Dutch Levant traded with Ottoman merchants and a predominant British trading community with Han frontier settlers. What is more, local connections in both places were a crucial factor that influenced the development of both locations. ${ }^{15}$

A factor, thus, for this comparison lies foremost at the centre of personal research curiosity. Having lived in both locations, the on-the-street similarities between the two warranted further investigation. What became clear in the initial survey was that irrespective of cultural differences, if the social conditions, (i.e. the economic, political, and social circumstances) are similar, people behave the same. It is instead within one's cultural 'habitus' (to borrow from Bourdieu) that the contexts differ. 
One notable condition was that the decisive shift towards a trade-based location owed much to the increase in available labour, and the sustained urban growth that both regions witnessed was born out of the extensive trade networks that they began forming. The pattern that emerged via this trade boom gave the initiative to a new style of cosmopolitanism and the stimulus for these changes was an increase in long-distance trade in items of 'daily mass consumption. ${ }^{16}$ Among other things, these included textiles and foodstuffs. The central role in managing this in turn saw the emergence of a new type of location and one with a greater emphasis on specialization in the production of certain goods in order to meet a long-distance demand. In the case of Dadaocheng, this was predominantly tea and camphor. In Deptford, this was first its role as a victualling yard, then a meat market and soap manufacturer. It is within these regionalized, export-oriented processes that functions of modernities (the plural being important here) transpired. These new demographics yielded new class structures and ideas of modernity began to be expressed by the emerging urban middle-class.

\section{BECOMING MODERN}

The middle classism that appeared in both locations from the mid-nineteenth century was defined not only by their profession, their wealth, level of education, and the things they consumed, but by the methods in which they had asserted their modernism. What is more, these patterns developed irrespective of the traditions of their respective societies. In Dadaocheng, for example, a sizable number of people adopted customs of Euro-American urban culture, but in no sense was their modernity indistinguishable from Westernisation. Instead, the very fabric of modernity was 'authentically' local. Simply recognizing the multiplicity of evolving modernities, one is able to thus identify a common core. ${ }^{17}$ The local and global connectivities 
that manifest in port towns and cities are according to Kenneth McPherson '[places] where the people of the region met and interacted with one another.' ${ }^{18}$ What is more, it was in this interaction that new spaces and new sets of relationships developed. ${ }^{19}$ What formed instead were other modernities — indeed, many modernities. ${ }^{20}$ Although a number of social and urban programmes that accompanied this were initiated by State-level actors, it was the adaptation of these programmes and their integration into the local environment that made them unique. This was especially true for those working in State-level programmes, such as commerce (clerks, accountants), public administration (civil servants, solicitors, teachers) and the financial sector (moneylending, banking, insurance). With the knowledge that they acquired in their occupations, they brought this back to their community.

\section{THEORISING ELITE FORMATION}

In the context of imperial China, particularly in port cities, one can see manipulation of gentry formation among different merchant communities, which led to the formation of the 'gentlemanly merchant' (shenshang, 紳商) and although, as argued by William Rowe, the vocabulary of class was yet to be developed on par with early modern European cities, specific terms for an economic strata were nonetheless present. ${ }^{21}$

Situated among the shenshang were the wealthy households, or fuhu富戶. Aside from tradesmen, these also included landlords (dizhu 地主). These were followed by the 'middling sort ${ }^{22}$ or $z$ honghu中戶 (occupations such as public administration, clerical officials, and heads of schools); then the artisans and shopkeepers, or small households, xiaohu小戶; behind which 
were the pinmin貧民 (paupers), and then finally the jianmin賤民, or 'filthy people;' a derogatory term to encompass those associated with begging, slave labour, and/or in occupations such as prostitution. Added to this was the imperial examination system, and it is here that the gentry typically were able to gain power through legal access to local officialdom. In the Deptford comparison, this is particularly clear in the rigid class system. Both locations witnessed significant changes in terminology that corresponded to a general decrease in the significance that had been ascribed to hereditary stature, and an increase in wealth and income as markers of position within the social hierarchy. Since power is situated only where it is believed to exist, this acknowledged them within a position of gentry. The institutional basis for this, for example in Shanghai, in 1850, can be seen within five new gentry-run charities. This was further significant in the fact that each of them represented a form of institutionalized elite power in public affairs. ${ }^{23}$ Among their many known functions was the feeding and clothing of the poor, the care of abandoned children (in particular, girls), and the burying of disposed corpses. Yet, importantly, as argued by Vivienne Richmond in her seminal work on clothing the poor in nineteenth century England, the 'poor' were not synonymous with 'lower orders,' in spite of the homogenous mass that contemporaries transnationally had assigned them. For the same reason, 'the poor,' equally, did not equate to 'non-elite'. ${ }^{24}$ In fact, the transition to wage labour, as argued by Eric Hobsbawm, meant that insecurity hung over the lives of most nineteenth-century workers, both in Britain and elsewhere. ${ }^{25}$ As the social conditions and labelling of 'the poor' transcended social boundaries, so did the functions of elite members of society. 
Accordingly, the social life of urban elites residing in Dadaocheng had certain structural similarities, and was anything but rigid. In practice, their social mobility is probably better represented in a comparative with their counterparts in other port cities and towns. The ability to purchase titles meant that wealth could equal status; something that privilege status among the Chinese gentry was not traditionally determined by. ${ }^{26}$ In a sense, what seemed to be happening was that the wealthiest residents of Dadaocheng were in fact forming part of an emerging transnational middle-class as opposed to following the traditional model of Chinese elite formation. This was not unique to Dadaocheng. The supplementation of revenue sources by the Qing State in China contributed to unsuccessful examination candidates gaining honorary titles as well as securing early promotion by already ranked professionals. ${ }^{27}$

In an attempt to redefine the theory of elites, Michael Woods addresses the following three factors: (1) Access to particular resources that can be used to exercise power or influence; (2) Network links (in the form of social or professional relations) which could be used in recruitment or the transmission of influence and patronage; and (3) Discursive construction in the sense that people are socially mobilized (either by themselves or others) as being elite. ${ }^{28}$ In most cases these changes were attributed to new forms of sociability and social activity. It is these urban dwellers, unlike their landed rural cousins, that not only sought wealth through trade but also were intrinsically linked to the group spirit which they possessed, whether real or imagined.

In the case of London, although rigid structures of imperial titles were absent, the hierarchical structures of class formation and aristocratic titles most certainly did exist. What is more, education played a vital role in ensuring middle-class ideals. The nineteenth century 
for many provided a great opportunity for social mobilization. Efforts were made, both consciously and not, to ensure that society was based on a system of merit as opposed to hereditary rights. Instrumental in this was education reform and the improvements in civic culture. Economic and political power forged by this new group had to be invented in their image (public styling). ${ }^{29}$ The increase in manufacturing and the growth of entrepreneurs- the shopkeepers and merchants—-was reflected in the upsurge of industry and overseas trade. This was coupled with the expanding need of commercial and financial institutions. As such, part of this growing band of people were managers, administration clerks, and other professionals who were needed to run and operate institutes such as banking and insurance, and oversee the needs of the shipping and railway industries. This, in turn, needed regulating. Opportunities, therefore, became plentiful for a wide range of government bureaucrats, civil servants, teachers, lawyers, and doctors. Yet, in spite of this surge in sources of wealth, the ruling elite, or 'Gentlemanly Capitalists' (wealth derived from land and financial capital) were able to negotiate and navigate, or even, at times, tame this emerging form of new capitalism.

At the very heart of this diverse new community was a real need to develop new spaces to accommodate them. ${ }^{30}$ Deptford, on the south-eastern embankment of the River Thames, became one such place.

\section{DEPTFORD - AN ISLAND IN THE MARSHES}

Deptford, previously known as Mertun (the town in the marshes) was, prior to the establishment of the Royal Naval Dockyard in 1513, little more than an 'island of [...] solid ground sloping back from the Thames and surrounded by bog-swamp. ${ }^{31}$ Yet it was not until the completion of both Westminster and Blackfriars bridges in 1750 and 1769 that South 
London began to expand and with improved roads around St. George's Circus the south became an attractive alternative as a cheaper place to live. ${ }^{32}$ The most sensational of this transformation amounted to 'Southwark (the Borough) and a ribbon of riverside industry up to Deptford, with the enclaves of Greenwich and Woolwich. ${ }^{33}$ Early nineteenth century Southwark was largely dominated by warehouses and filled with slums. One notable location, made notoriously famous by Charles Dickens in Oliver Twist, was Jacob's Island - the home of Bill Sykes—in present-day Jacob Street, Bermondsey. ${ }^{34}$ So vividly described:

Near to that part of the Thames [...] where the buildings on the banks are dirtiest and the vessels on the river blackest with the dust of colliers and the smoke of close-built low-roofed houses [lies the] crazy wooden galleries common to the backs of half-a-dozen houses, with holes from which to look upon the slime beneath; windows broken and patched, with poles thrust out on which to dry the linen that is never there; rooms so small, so filthy, so confined, that the air would seem to be too tainted even for the dirt and squalor which they shelter; wooden chambers thrusting themselves out above the mud and threatening to fall into it—as some have done; dirtbesmeared walls and decaying foundations, every repulsive lineament of poverty, every loathsome indication of filth, rot, and garbage. ${ }^{35}$

Development of the south was often slow and piecemeal but with the linking of Watling Street (present-day Old Kent Road) with the southern end of Westminster Bridge, the transformation of Southwark quickened. With an urbanizing project in full force, an Act of Parliament was obtained on 21 May 1801 for the construction of the Grand Surrey Canal. ${ }^{36}$ Completed in 1826 , the canal was used primarily to transport timber ('deal') to the Surrey Commercial Docks.

The authorized canal, which stretched from Rotherhithe on the Thames to Mitcham, included Deptford. Despite being just shy of two hundred yards from the core of London's 
power, the south sat in obscurity. It was at the lowermost of all but a few of the eighteenth- and early nineteenth-century maps of London. Maps such as John Rocque's in 1746 clearly allude to differences in density. According to Tindall, even as late as the 1830s, the parishes of the south fought for autonomy to form a 'township separate from the capital (a true 'Borough') with its own corporation, magistrates and judges. ${ }^{37}$ The Directory of 1823-4 references Deptford as 'a large town three miles from London...remarkable for its noble docks, in which large number of hands are employed. ${ }^{38}$ Dadaocheng, in comparison, was recorded as being 'some eleven miles from the port of Tamsui'. 39

By the 1880 s Deptford could generally be fitted into a comparable concentric zone model created by sociologist Ernest Burgess in 1923. According to the Burgess Model, the inner ring formed a working class zone that reached as far as Southwark and Lambeth; rents were expensive principally due to labour competition within industries. Tenements were overcrowded largely due to land being sequestered for the building of railways. The quality of food to be gained from the market was poor and not expensive, and work was readily available for all members of the family. ${ }^{40}$

On the outer-ring lived some of the older 'more socially mixed communities' that were built to accommodate 'respectable' working class families who had relocated from central London to places such as Lewisham. The peripheral 'commuter ring' saw the wealthier residents moving to country villages such as Bromley and Blackheath. This is in stark contrast to Dadaocheng. The manner in which Dadaocheng was established did not follow typical migrations (this will be discussed fully later). Yet in July 1899, when Charles Booth arrived on Deptford High Street to survey and incorporate the area into the social map of the city, much of the original concentric separation of class had disappeared, and it is here that the comparison 
is better reflected. What Booth recorded was a mix of middle-class well-to-do streets, which he coloured in red on his map, and streets with both comfortable and poor residents living together, which he shaded a paler fuchsia. ${ }^{41}$

In his notebooks, Booth recalls starting on the north side of Deptford Bridge on 18 July 1899, with its three-storeyed shops and Gardiner's large establishment occupying its corner. These were easily marked in red. Proceeding to Deptford Broadway, Booth recorded the triangular meeting space that was paved with cobblestones, and although Booth reported the Broadway poorer than Church Street, he still marked it in red. On Church Street itself, Booth records that the street housed a poor class of shops on its perimeter with the Broadway, which was mixed with three-storey buildings and old-fashioned private houses. In addition, there were a few let-in tenements that to him looked 'comfortable.' Most notably there were two 'formal lodging houses' on High Street with male-only occupants in varying labour-intensive industries. ${ }^{42}$ Proceeding south along Church Street to Reginald Road, Booth recalls seeing twostorey properties, some of which were modern and others covered with creepers. On the north side of Reginald was the Mission Church, and the Girls' Friendly Society occupied the south. Booth marked this in pink. West of Reginald was High Street. Booth writes that this was a large market street with two- to three-storeyed properties with numerous building styles. The only thing uniform was that they all had shop fronts. Most owners lived above their shops, and the wealthiest of these were on the north end near the Broadway. This was clearly marked in red. $^{43}$

On High Street, Mr. George Brading, a stationer from the Isle of Wight, for example, lived at number 26 with his wife Ann. ${ }^{44}$ Next door to them, at number 28, was Henry Carter (a native to Deptford) who lived above his fancy goods shop with his wife and three children. 
They also had one domestic servant, Rosa (also from Deptford), aged 18. The census data for 1891 reveals that elsewhere on High Street the occupations of its residents varied in ways that are probably representative of most high streets.

After relieving the Inspector at the corner of High Street and Creek Road, Booth continued to record the greater part of 'poor Deptford. ${ }^{45}$ This 'poor Deptford,' one where there was 'not so much crime or violence,' was probably a reflection on the state of the buildings and its use rather than a complete picture of the societal position of its occupants. For example, Booth records the following on Reginald Street: '[B]roken windows. Some street sellers. Two women talking in roadway as we entered. "Well-known prostitutes" said the Inspector.' And yet within a short walk on Reginald Road: 'A few are modern on the south side [...] Some covered with creepers, clean curtains. Nice little houses. ${ }^{, 46}$

By looking at the census data this becomes much clearer. At 13 Reginald Street was an almshouse with eight boarders (all over the age of 60) and two servants (Ann and Elizabeth Meggit). Next door at number 11 lived the Hare family. George, aged 40 (a store labourer) lived with his wife, Mary, and their seven children, the eldest of which, George (18) and Henry (16) were butchers' assistants. The other four were at school while the fifth, Rose, was only eight months old. In other houses on the street, there lived others in similar circumstances. George Orchard at number 7 was a coachman, Fredrick Miller, at 24, was a boilermaker, and at 19 Reginald Street lived Mary Ann Howell who was part of the church mission. Looking at Reginald Road — the 'nice little houses'—we don't see much difference in social occupation. At May Cottage lived Samuel Rutherford, a bricklayer with his wife Elizabeth and three children. At number 6 lived Edward North, a coachman to the undertaker (an occupation shared by his eldest son). North's younger son worked as a milkman, and the other children were at 
school. Going through the schedules one finds similar social circumstances and evidence that little separated the two streets. Aside from the almshouse on Reginald Street there does not seem to be many listed as living in domestic service; though it is important to stress that this does not mean that no house employed domestic labour; they simply did not reside there. This was again repeated in other streets even among middle-class neighbourhoods such as on Evelyn Street. At 215, for instance, lived William Augustine [?] a physician and surgeon who lived with his wife Adila and one servant, Annie Marsden. Yet at 249 there was Carl Schmidt from Bärwalde, Germany, who was a Master Tailor but had no 'live-in servants.' This was repeated at number 250 (George Green, a musical instrument maker); again at 244 with William Knapp, an inspector at the Metropolitan police; and with William Cockle at 230, who was a lawyer.

Despite the absolute poverty (the almshouses on Reginald Street), to the middle-class well-to-do families on Evelyn and Broadway being in close proximity, it seemed that the neighbourhood had a degree of interaction with each other. Further research into the employment of sisters Isabella and Annie Wellcock, for example, at 3 Union Terrace, who were listed as domestic general servants, may well uncover local employment in the middle class neighbourhoods. ${ }^{47}$ Employing domestic help from within the community could arguably be seen as being part of a collective mutual aid assistance to the wider neighbourhood.

In Dadaocheng, it was tea (and the preparation thereof) that dominated the occupations of a number of its residents. For instance, on Jianchang Street, Quanqiu Street, Liuguan Street, and Jianchang Back Street, most if not all of the residence buildings were tea-related shophouses. $^{48}$

Housing in nineteenth century London and Dadaocheng were profoundly related to class. The multiple-room and single-room housing (those marked in red on the Booth maps) 
was almost always reserved for the middle and upper classes. The poor, or working classes, frequently found themselves tenanted or in overcrowded apartments or slums. The location of these, in the context of Deptford, formed an important role in the development of London society. The cheek-by-jowl living that is evident in the Booth maps is telling. It relates to the manner in which these 'middling sorts' obtained wealth. The development of the shophouse provided a space from which the ground floor space was used for mercantile activity with the residence above the shop. This kind of mixed-used building style was largely a result of the processes of urbanisation that were typical of the period. Its differences with regards to these two sites lie in its regularity. In the case of Dadaocheng, these more regularly vernacular architectural styles are more common in urban Southeast Asian areas and are representative of the style of building preferred by Han Chinese settlers. This is evident in Malaysia, Singapore, Hong Kong, Thailand, the Philippines, and even in 'Chinatowns,' such as those in San Francisco and New York. As Dadoacheng was largely settled by Han Chinese migrants, this style of architecture is not surprising. For Deptford, however, this was exclusively concentrated on the High Street and this is typical of most, if not all, high streets/town centres.

At 10 High Street, for example, Mr. James Rowley had leased out the other rooms in his home to nine boarders (three of whom were salesmen in his shop). In addition to this, he also had three servants: Ann, Caroline, and Annie, aged 40, 20, and 24 respectively. ${ }^{49}$

The proximity to the river meant that lodging could be a short-term affair. On Evelyn Street, for example, at 249, Thomas Callo, a medical student from Gateshead was lodging in the house of Edward W. Kirksworth[?] for the course of his study. ${ }^{50}$ What is more, given the range of lodgings and their close proximity to each other, the experiences often varied greatly. They not only provided temporary housing for ships' crews, freedom from family life for well- 
to-do bachelors and for less well-off spinsters, but they also provided lodgings for apprentices and workers of the retail establishments that occupied the ground floors. As such, the riverside position of Deptford played an undoubted importance in its growth. ${ }^{51}$ The practice of lodgings on the harbour-side properties was common in Dadaocheng and its satellite districts. In 1872, for example, George Lesley MacKay from the Canadian Presbyterian Mission wrote how he was housed by British tea merchant, John Dodd, in his residence. ${ }^{52}$

The platonic ideal of what a home should look like drove the middle-class to adapt their environment to meet the archetype 'homeness' that they imagined. Instinctively, that 'home' was based on a concrete and unchanging thing. Their ideals, through interaction, books, and images shaped its design: the domesticity of homeness. Their designs, in turn, were patterned by the occupations that the households engaged in and fixed notions about the values of family life.

Shortly after the dissolution of the East India Company in 1858, the shipyards at Deptford closed. The victualling yard, however, continued to resupply naval warships and merchant vessels, providing them with the necessary goods for their voyage. The supply of such wares was an important local industry for many of the retailers in the district as well as necessary labour for its other residents. For example, in the 1891 census, Arthur Green, who lived at 74 High Street, was a grocer whose goods would more than likely have been supplied to the victualling yard. His son Arthur, aged 15, worked as a shop assistant. A similar narrative would have also been found at the fishmongers at 60 and the butchers at 46 and $13 .{ }^{53}$ At 236 Evelyn 
Street, in the same census, this is much clearer with Henrietta Gore (a widow) being listed as a licensed victualler.

In 1742, the Victualling Board rented the Red House estate (now Grove Street entrance to the Pepys Estate) for the purpose of establishing a main depot. It was here that the namesake of the famous hard Red House Biscuits were baked. ${ }^{54}$ Construction continued with the inclusion of mills and warehouses. Aside from its own dockyard, the scale of the yard was also supplying ships further downriver at Woolwich, Sheerness, and Chatham. In 1858, the yard was named the Royal Victoria Victualling Yard and followed similar brandings of the yards in Portsmouth and Plymouth.

By 1805 , the victualling yard had already incorporated a slaughtering house for oxen. Yet in 1871 with the opening of the 23-acre Foreign Cattle Market to replace Smithfield Market on Charterhouse Street, the opportunities for employment were well received despite the 'horrors of the smell' and the 'streams of blood flowing down [the River] from the cattle sheds. ${ }^{55}$ Perhaps the most striking feature was the employment of women—or 'Gut Girls' as they were known locally_in the offal sheds. Ranging from 14-40 years of age, they were earning a relatively good wage of 10-13 shillings a week (roughly $£ 30-40$ in today’s money). Yet the 'feminizing' of butchery work was not without criticism. The interplay of patriarchy and capitalism in the workplace was such that, in certain occupations, unions and friendly societies were largely formed on skill-craft-based employment and were able to use this membership to exclude women from apprenticeships, thereby controlling the number of workers entering the trade. ${ }^{56}$ The changing working patterns for women following industrialisation, however, provided an alternative to the main source of income for the same 
demographic: domestic service. According to Hilda Kean, 'those working in its yards were contaminated by their very job. ${ }^{57}$

Education, or the ability to read, amongst girls from wealthy family backgrounds, for example, in Dadaocheng was predicated on their ability to read account ledgers. ${ }^{58}$ This was referred to as toujianiang頭家娘or 'lady boss'. It typically used to refer to a 'shop owner's wife,' and the boundaries between 'public' (that of the shop) and 'private' (home) began to blur. Chen Huiwen argues that the role of a 'lady boss' is indicative of not only the 'entrance of women into commercial work' but it also reflects the hidden reality that through this entrance the responsibility of the woman increased. This role was to become a dominant feature of the commercial landscape during the Japanese colonial period. ${ }^{59}$ In Britain, this was arguably seen in the number of women entering the labour market as retail workers. The attraction, as argued by Pamela Cox and Annabel Hobley, was not immediately obvious. The working hours for girls in retail were longer than their factory-working equivalents. For Cox and Hobley, it is evident in newspaper advertisements that sported words such as 'respectable,' 'young,' 'good character' 'knowledge,' 'abilities,' '[t] he spin [that was] clear: shopwork was being advertised as suitable for young women, a proper profession, a job with status." 60 The situation in Taiwan seems to mirror this. Modernity brought with it a number of changes. Economically, more opportunities for employment began to materialise, and with them more women were becoming free from 'bound feet,' and these young girls began to fill this gap in the market. ${ }^{61}$

With an increase in the need for female literacy, it is not surprising that this went handin-hand with the establishment of educational institutes catering for the poor. Chief among the associations that were entrenched in Deptford was the Albany Institute (now the Albany 
theatre). Established in 1894 as The Deptford Fund by a group of philanthropists, its main goal was to improve what they considered the 'plight of Deptford's community.'

By 1903 that 'plight' was being extended to an increase in the number of soup kitchens and a more systematic effort to remove women from the cattle market and into more 'fitting' employment: domestic service or factory work (if lucky: retail). It was felt that the additional money that was being earned from working the sheds was only spent on drink and resulted in 'secondary poverty.'

Rough women are on the doorsteps, one of them with a bandaged head, others with black eyes. Shoeless children run about, an old harridan sits smoking a clay pipe. The prevailing dirt make itself felt by a faint foetid smell, overpowered by disgusting stenches. ${ }^{62}$

The Deptford Fund was the creation of Viscount and Viscountess Templeton and its charity was developed from 1895 with the patronage of the Duchess of Albany, Princess Helena (wife of Leopold, Queen Victoria's youngest son). Although the area clearly had a rising middle class, the Albany Institute (as it later became) lacked their support - many saw the 'aristocratic invaders' as nothing more than 'supercilious outsiders ${ }^{33}$ — and had to rely instead on local working class volunteer helpers. The 'girls' who subsequently sought alternative employment were able to use their 'membership' as a guarantee of 'respectability'. The desire for this 'rescue work' is interesting especially since attendance grew rapidly towards the end of the century. In 1895 the average attendance was 28, with 35 members. By 1905 this had increased to 288 and 360 respectively. ${ }^{64}$ By 1912 many of the girls who first attended the 'Slaughter House Girls' Club,' as it became known, were now married and a new 'Married Girls' Club' was formed; later changing to a 'Mothers' Club.' 
Looking at the census data for the district, what is particularly striking is that although it was known that many of the local women were in full-time employment at the market, very few listed it as a place of work. Instead, many chose either to record no occupation or listed themselves as either charwomen or firewood cutters. This was especially noticeable in the Mary Ann building (now Maryann Gardens) on Union Street, which was well known for housing slaughterhouse girls.

The formation of the 'Girls' Club' was considered necessary since its organisers believed that they 'could improve these 'rough and unkempt' women through contact with 'refined ladies' and by providing them with useful and wholesome activities. ${ }^{65}$ On Reginald Road, an additional establishment was erected with very similar ideals. The main aim of the Girls' Friendly Society (established 4 years after the Foreign Cattle Market) was to encourage charitable work among working class women. It was originally open to unmarried girls from 14 years onwards, but by 1879 it was admitting girls as young as $8 .^{66}$ In Deptford, like the Albany Institute, its chief purpose was to assist in moving girls from the slaughterhouse into service, thereby not only reducing their salary but also increasing their hours of work.

Social activism and political participation, in the context of Deptford, was not just an aspiration of the middle-class elite. Impoverishment stimulated radical grassroots change. Charles Rubery, a boilermaker from Deptford, for example, led the Deptford Working Men's Co-Operative Provision Association. John Longmaid, a tailor from Greenwich, went from being a Chartist to playing a role in the local branch of the Reform League and the Deptford Radical Association. ${ }^{67}$ 
The course of Deptford's expansion changed dramatically through the nineteenth and early twentieth centuries. From its powerhouse as a naval dockyard to a cattle slaughterhouse, and then to the entanglement of railway lines and associated industries, the area consistently attempted to thwart poverty and yet with each new industry the living conditions for most remained shockingly low and unemployment continued to be rampant as more people migrated to the district in search of work. As a result of this, Deptford provided the perfect stage on which political, social, and — to a certain extent—religious reform were enacted. ${ }^{68}$ Although it is generally accepted that local politics are often intrinsically linked to national developments, they do not necessarily reflect the overall national picture. The class-conscious, dissentingradical politics that appeared from the nineteenth century onward was influenced by local specific community experience. ${ }^{69}$

Changes to the quality of life for the 'middling-sort' in Deptford, like elsewhere in London, improved over the course of the nineteenth century and a reasonable standard of living was enjoyed by a larger number of people. One symbolic measure of this was the use of gas for the lighting of streets and domestic spaces from the $1870 \mathrm{~s} .{ }^{70}$ Gas to the ecclesiastical district of St. Pauls was supplied by the Surrey Consumer's Gas Company (later amalgamated with the South Metropolitan Gas Company). In 1881 there were 863 gas lamps, lighting approximately 34 miles of road. By 1891 this number had increased to 1179 , and its reach to 40 miles. $^{71}$

One of the most important indicators of social well-being is indubitably education. Deptford in 1870 fostered charity schools that ran along national lines. The St. Nicholas National Society School (est.1833) was situated at Hughes Field. The St. Paul National Society School in New Street (est.1839), the Addey Foundation School and the Stanhope School (both 
endowed) were elementary education institutes. ${ }^{72}$ The Stanhope School originally stood on High Street prior to being demolished to make way for retail. It subsequently moved to its namesake on Stanhope Street. It was founded by the vicar at St. Nicholas, George Stanhope, in c.1700. The Addey Foundation School was an endowment school funded by John Addey a shipwright. Children attending had to pay $1 \mathrm{~d}$ per week (equivalent to roughly $£ 63$ in presentday spending). The schoolhouse, with its attached accommodation for one schoolmaster and one schoolmistress, sat on Church Street. Children at this school were singled out for good behaviour and given prizes of "costumes. ${ }^{73}$ In order to cater for the poor, there was also a school that adjoined the Methodist Chapel in Mary Ann's Buildings and one that sat under the arches of the London to Greenwich Railway (est. 1843). These were run 'along Lancastrian lines' and housed 80 children.

With the Education Act of 1870, the number of schools in Deptford rose dramatically through the period of 1870-1895. Mundella's Act of 1880 saw compulsory education for children between five and ten. This coupled with The Sandon Act four years earlier (which forbade the employment of children under 10) meant that there was greater incentive among poorer families to send their children to school. ${ }^{74}$ By 1895 , there were seven boarding schools in Deptford. ${ }^{75}$ The schools catered for boys as well as girls. Philanthropy in the district extended beyond the establishment and running of schools. Richard Wheen and his brother John, who went into the soap manufacturing business, were by 1837 producing 625 tons of soap annually in a factory on Ratcliffe Highway in Finsbury. The following year this figure had risen to 715 tons. The two brothers decided to split in 1849 and Richard moved the workshop into a former pin factory on Creek Road in Deptford. ${ }^{76} \mathrm{He}$ and his family located to neighbouring Blackheath, but he was reported to have travelled in on a daily basis. In order to assist the local 
population, Wheen opened rooms within the factory for the timekeeper and his family. In the 1891 census these rooms were let to John Crook (58), his wife Ann (55) and their daughter Elizabeth (27). ${ }^{77}$

Despite the clear attempts by the local elite to provide relief for the poor, much of the neighbourhood surrounding them continued to be poor. Charles Booth identified that 73.3 percent of East Deptford lived in poverty. On the other side of the district (in the west) this was 40 per cent. In total, 34.6 percent of the population lived in poverty. ${ }^{78}$ This is significant if one considers the fact that Greater London as a whole had a poverty rate of 30.7 per cent. In addition, as indicated in the Aubrey Institute's report, the growth in soup institutions is indicative of rising levels of poverty. According to the Deptford Soup Institute report for December 1831, it was estimated that every month 23,000 quarts (a quart is equal to almost a litre) of soup and 4 tons of bread were distributed to the most needy. It was funded by a group who titled themselves the poor's 'Benevolent Neighbours and Friends' and were largely made up of church groups represented by the urban elite. ${ }^{79}$

For the most part, new forms of sociability were genuinely reflected in a concerted effort by the emerging elite to address poverty within their neighbourhoods. How the organizing few were able to access donations was very much part of an exercise in social power. This is especially true if this is measured by the lack of support given to the aristocratic 'outside' institutes, such as the Albany and Girls' Friendly Society. By using new forms of patronagethrough social and professional relationships - they were able to channel their networks. In Taiwan these forms of patronage were known as yaohui搖會, xiehui寫會 and yaoganhui 搖干 
會. Much like their British equivalents, these were established to assist in funding funerals and the treatment of illness, as well as setting up new businesses and providing relief to the poor during religious festivals and marriage ceremonies. During the Japanese colonial period, it was the yaohui that remained popular and provided relief for the poor through community involvement. $^{80}$

In Deptford, men such as Mr. Wegg and Mr. T.L Carter, who oversaw the delivery of soup every Thursday evening and Friday morning, respectively, were part of the board of 'Benevolent Neighbours and Friends' and were able to (through discursive constructions), obtain financial assistance from people such as Mrs. Drake, who donated £1, and Captain Usher, who gave $£ 5$ (roughly $£ 60$ and $£ 300$ in present-day spending worth) ${ }^{81}$ Similar forms of elite identity formation and mutual aid associations transcended national boundaries and were part of a much wider form of social influence among a growing nouveau riche.

\section{DADAOCHENG: A PATCHWORK OF DIVERSITY}

Despite its recent history, the narrative of how Dadaocheng developed is remarkably complex. ${ }^{82}$ It is closely integrated into the history of Chinese pioneer settlement and the establishment of the jiao郊system that followed the legalization of family migration between 1732 and $1740 .{ }^{83} \mathrm{As}$ a consequence, both settlement and reclamation in the north were principally different to that which had been carried out in the south since Dutch times (16241662). To Ronald Knapp, the reclamation of land was 'not only regarded as a criterion of merit for local officials; it was also an easy way for prominent individuals to acquire wealth. ${ }^{84}$ By complying with the rules laid down by the Ministry of Revenue ( $h u b u$, 戶部) all land on Taiwan 
could now legally be purchased. To manage this, Dadaocheng formed part of the Tamsui subprefecture that included land starting from the Dajia River in its southernmost extremity to the port of Keelung in the north. ${ }^{85}$

In spite of the legalization of land purchase, the continuous fluctuation of Qing policy generated a complicated history, which revealed the government's inability to utilise Taiwan's comparative advantages. This lack of consistent direction led the economy of Taiwan in the eighteenth and early-nineteenth centuries to become strictly closed. Prohibition on migration of families gave rise to an unstable society of male migrant labourers. Yet those colonists who had braved the dangerous strait came to Taiwan because they wanted to pursue economic selfinterest without strict interference from the state. ${ }^{86}$ This resulted in the frontier frequently opposing any sort of bureaucratic control. According to Henry Tsai, between 1684 and 1895 there were a total of 159 major uprisings and from 1768 to 1887 there were a reported 57 armed confrontations. ${ }^{87}$ This led to the popular verse that: 'every three years there was an uprising and every five years a rebellion [sannianyixiaofan, wunianyidafan,三年一小反, 五年一大 反].'

Yet, in spite of the frequency of violence, farmers continued to plough their land and grow their rice, sugar, and other important crops for the purpose of exporting trade across the strait. ${ }^{88}$ In turn, the settlers became firmly embedded in a capitalist economic system and organized themselves into localized versions of their regional kin networks or bentuhua本土 化; namely Hakka, Zhangzhou, and Quanzhou. ${ }^{89}$ In spite of such rigid networks, social conflict, in its many forms, continued to prevail as more urban centres gradually opened..$^{90}$ The 
expansion of the economy instead of destabilizing ethnic violence in fact aided mutual cooperation as market competition began to replace factionalism. ${ }^{91}$

On the other side of the Taiwan Straits, disputes over trade led to war between Britain and the Qing Empire. Known collectively as the Opium Wars, the first of these witnessed the cession of the island of Hong Kong and the establishment of five treaty ports (Shanghai, Canton, Ningbo, Fuzhou, and Amoy in present-day Xiamen). The second, fought for the legalization of trade in 'opium and coolies,' saw an increase in the number of ports opened; a figure that would eventually exceed 80 . The island of Taiwan, as a result, had four ports designated for international trade.

The treaty port on the River Tamsui was established in 1862 by British Vice-Consul and botanist Robert Swinhoe, who had a year earlier been given the task of establishing British trade on the southern part of the island. Swinhoe felt that trade in the north would be more substantial in spite of reports that the location was no more than 'an anchorage [in] a straggling fishing village near a river-mouth. ${ }^{92}$ Dadaocheng up to the same period was a small village close to the main frontier town of Mengjia (also Banka). The area had been used mainly for the drying of rice (hence its namesake ${ }^{93}$ ) and other agricultural produce.

In 1851, a Quanzhou immigrant, Lin Lantian 林藍田, moved to Dadaocheng from Keelung. There he constructed three properties and converted them into the earliest known retail establishments in the district. Two years later, in 1853, a serious conflict broke out between members of the Quanzhou Sanyi, 三邑 clan and the Quanzhou Tongan, 同安 clan in Mengjia. The people of the Tongan clan lost and were forced to leave the area. In Dadaocheng, they built new houses and temples along the riverside, and soon a new market was formed. 
Thenceforth, every time violence between rival clans broke out, those exiled moved to Dadaocheng and a new settlement of peoples formed around that original centre. This is particularly important in that Dadaocheng became an area that was far more tolerant to people of different clans. What is more, it was more resilient in accommodating the arrival of foreign merchants than its neighbour and competitor, Mengjia. This is particularly evident in the census of 1898 , when the population of Dadaocheng $(31,533)$ overshadowed Mengjia $(23,767) .{ }^{94}$

The initial survey carried out by the Japanese in 1897 clearly demonstrates that the streets of Dadaocheng were becoming highly diverse. The houses along Jianchang Street, 建昌街, Qianqiu Street,千秋街, Liuguan Street, 六館街, and Jianchang Back Street, 建昌後街 all had a mix of both foreign and local residents.

Though bereft of micro-historical data on individual families, The Special Population Census of Formosa of 1905 does contain important and relevant 'big data' in the form of population density statistics, literacy rates, occupation, languages spoken, number of bound and unbound feet in the local population, and the number of infirm people and the nature of their disability. ${ }^{95}$ By the time of the 1905 census, the market-town of Dadaocheng was well on its way to becoming part of a statistic of a greater Taipei (J. Taihoku) area. Although it would maintain its sense of identity throughout the period, its initial resistance to becoming part of the neighbouring city slowly eroded.

The city wall of present-day Taipei was completed in 1884, making it the last to be built in imperial China. It was largely destroyed over the years following the Japanese arrival as part of their initial restructuring assessment. Its original layout was built on farmland between the market-towns of Mengjia and Dadaocheng. Since the building of a cheng城, or city, required 
specific applications, the new administrative centre would need to incorporate three levels of administration (Danshuixian 淡水縣 Tamsui county, Taibeifu 台北府 Taipei City, and Taiwansheng 台灣省 Taiwan province), meaning that certain infrastructure, such as prisons and schools, would need to be shared. Since Dadaocheng (also Deptford) by the 1880 s were locally entrenched, there was significant resistance to incorporating the neighbouring city into their urban planning. A major factor in the case of Dadaocheng was that this locale was considered the heart of a Taiwanese community, whereas Taipei City was, by the turn of nineteenth century, Japanese and very much part of a colonial urban project.

In the case of Deptford, for example, unlike other suburb districts brought closer to the metropolitan centre by the establishment of the railway, Deptford did not take its character from the fortunes of the nineteenth century. Instead, it was one of the older settlements that had gained a degree of prominence in the sixteenth century. It had built itself as being independent from the metropole. Self-sufficiency and localism were part of the social fabric of the community. It had its own industries, own middle class and its own 'web of internal social relationships'.96

Dadaocheng was similar in that localism was the fabric of the community. Its identity was formed on a separation from the neighbouring market-town of Mengjia. The residents did things differently. Prior to the colonisation of the island by the Japanese, the walled city of Taipei was developed on land largely owned by one family: the Hong 洪. ${ }^{97}$ Inside of this walled city, apart from the Hong ancestral home, all other building were bureaucratic offices and since the establishment of a capital city would result in higher taxes, the urban elite in both 
Dadaocheng and Menjia had pushed hard to have the capital located away from their centres. Both set of elites nominated Hsinchu, an area much further south. In addition to this, the urban elite who by 1884 were now living cheek-by-jowl with their foreign mercantile counterparts and rivals were concerned about the impact that incorporation into the city would have on this relationship.

The first Japanese Governor-General, Kabayama Sukenori, attempted to control this foreign presence within the district. However, Dadaocheng in many ways proved difficult as residential areas, unlike those in treaty ports throughout the rest of East Asia, found no separation among foreign and local people. A major factor for this was that the land on which the foreign firms were established was owned and purchased by them. ${ }^{98}$ The sale of land would have either been drawn up under the Chinese comprador's name or within a business transaction as a means of avoiding further complication of ownership from the Qing court. ${ }^{99}$ These kinds of agreements would elevate the degree of interconnectivity between the two.

Over the course of the nineteenth century, international situations brought this new community closer together. The Japanese expedition of 1874 had an impact on the perception of the British community due to their assistance (through Thomas Francis Wade in Peking and Harry Parkes in Japan) in providing the Qing court with detailed accounts of Japanese naval movements. ${ }^{100}$ A decade later, the Sino-French War (1884-85) and the subsequent yearlong blockade of northern Taiwan enabled the local Taiwanese to make clearer distinctions between people of different European backgrounds. ${ }^{101}$

Following this yearlong blockade, Taiwan was upgraded from a prefecture to a province in its own right (October 1884). The first provincial governor, Liu Mingchuan 劉銘傳 invited 30 | Page 
merchants Li Chunsheng 李春生, and Lin Weiyuan 林維源 to invest in the Dadaocheng area. ${ }^{102}$ Together they built two streets: Jianchang Street 建昌街 and Qianqiu Street 千秋街. The buildings that ran along the streets were all two-storeyed Victorian-styled townhouses and equipped with floorboards and fireplaces. The two streets, which were completed in spring 1889, became a major location for the settlement of foreign merchants, many of which followed John Dodd, a British tea merchant, who had moved his factory from Liaoguan Street in Mengjia (liaoguanjie, 料館街; present-day Huanhe South Road, 環河南路) to Liuguan Street, 六館街 in Dadaocheng in 1872, where this larger establishment, known as 'the Old Bluff,' could fire tea in situ. As in London, the plots that lined these streets in Dadoacheng were produced for superior clients - businessmen and clerks - and similarly, the demand rarely met the supply. Roy Porter, on London, writes that 'in 1881 two in five of the 4,800 houses [built in] East Dulwich couldn't find a buyer'. ${ }^{103}$ Like Dadaocheng, this was of little comfort to the poor, whose needs for housing were never met. This in turn contributed to low urban density, a feature that was remarkably dissimilar to other major cities, such as Paris, Tokyo, and especially New York. With the ability to spread, districts such as Deptford and Dadaocheng were able to be consumed by the giant arising around it without planning or government direction. The power of the market kept migration coming to the districts and any aspiring folk would seek to firmly establish themselves or seek new alternatives elsewhere. Places such as Deptford began to lose some of their 'old and respected inhabitants' from the 1850s onward. However, there was no major or significant exodus of the prosperous throughout the period. ${ }^{104}$ In Dadaocheng, a similar occurrence happened in 1895 when Taiwan became part of the 
Japanese Empire. Notable families did leave for the mainland of China, but overall this had little impact on its prosperity. ${ }^{105}$

In Dadaocheng, one factor for this was the genuine steps made by the first governor of the Taiwan province to modernise the island. Arriving on the island in July 1884, Liu Mingchuan was determined that 'self-strengthening' required a 'thorough reorganization' of the entire island. ${ }^{106}$ His immediate plans became unpopular in the traditional south, not least because he chose to ignore the south in his plans for infrastructural development. ${ }^{107}$ The urban elite, who lived close to the new provincial city (particularly those in Dadaocheng) began to benefit from this self-strengthening program. ${ }^{108}$ Mobility was thus spurred by great material transformations. Deptford in this regard is a great comparison, not least in the formation of the railway. To continue this, funding meant solidifying the fiscal basis upon which all this rested. In the case of Dadaocheng, this was partially met through temporary financial assistance from Fujian province. ${ }^{109}$ Yet this grant satisfied no more than half of the annual provincial needs. Liu Mingchuan in 1886 then sought permission to raise likin (lijinju, 嶅金局) from exports of rice and sugar, and to increase the tax on commodities that were monopolized by the foreign community (export: tea and camphor; and import: opium). This aggressive economic outlook was provoking to both Chinese and foreigners alike, but it was largely achieved by disseminating modern ideas via foreign technical and military advisors employed at schools, which then offered courses in modern and foreign subjects, and by offering political incentives to local traders. ${ }^{110}$

One way that this was done was the designation of Dadaocheng as a special administrative trading district in 1885 , and housing one of the island's four tax bureau offices 
on Jianchang Street 建昌街. As many foreign investors had already settled there, various

Chinese entrepreneurs also entered the competition, many of whom had chosen to leave their former jobs as compradors to establish their own businesses. ${ }^{111}$ One notable example of this was Li Chunsheng who had worked for Dodd \& Co. Remaining close to both the Qing officials on the island and their foreign counterparts in the district, part of their tax was used for the improvement of infrastructure.

This policy was not without success. Customs records for 1886 (the year that the likin tax was introduced) showed little effect on trade. That year yielded the same quantity of tea as the previous year, which was then reported to have been the largest crop produced on the island. ${ }^{112}$ Working closely together, former compradors from Canton, Shantou, and Xiamen, together with their foreign counterparts, formed a merchant association known as (mazhenguan 媽振館, mazhen being a direct transliteration of the word merchant). These establishments with branch offices in the provincial capital, Taipei, Canton, and its head office in Xiamen offered loan services (maiqing 買青) either directly to the farmers or to the traders in Dadaocheng. The foreign-run tea companies, known locally as fanzhuang 番莊, specialized in Oolong tea, while the Chinese companies—-known as pujia 鋪家—-specialized in Baozhong tea. ${ }^{113}$ In spite of the fact that mazhenguan agents had substantial assets and were familiar with Western commerce, without any knowledge of the modern banking system, they needed to acquire capital via the larger foreign trading companies, which in turn borrowed on their behalf from the larger commercial banks. By providing low-interest loans, Huang Fu-san argues that the mazhenguan 
houses were the precursors of the modern banking system that was established in Taiwan under the Bank of Taiwan Act in April 1897. ${ }^{114}$

The local moneylenders (huiduiguan 匯兌館), which were commonplace throughout Taiwan in the Qing period, lent money in a similar manner (though on a much smaller scale) to the mazhenguan by offering loans either directly to the farmer or to the traders. Many famous huiduiguan such as Qianyu謙裕, Yingfang英芳, Yiyue怡悅 and Lianxing聯興, all had branches in Dadaocheng. ${ }^{115}$ In order to simplify and compete with these moneylenders, a number of large commercial banks employed the foreign trading firms in Dadaocheng as agents. Examples of this can be found in Cass \& Co. as representatives of the Hong Kong Shanghai Banking Corporation (HSBC), Tait \& Co., with the Bank of England, and Jardine Matheson \& Co., with the Yokohama Specie Bank, Ltd. Research on wealth holding in nineteenth century Britain suggests that, as in Taiwan, wealth was being derived from the financial sector, such as moneylending, banking, and insurance, and was always greater than that being made in industry. ${ }^{116}$

As such, banking would later go on to become a defining characteristic of the gentry. In Taiwan, prominent among these, in figure 1.0 (from left to right), are Lin Xiongzheng林熊 徵 (from the Banqiao Lin family, 板橋林家) who founded the Hua Nan Financial Holdings Co. Ltd. in 1919, which is currently chaired by his son, Lin Mingcheng, 林明成. Next to him is Gu Xianrong辜顯榮, whose family form part of the Koos Group (KGI), a pan-Asian business conglomerate that includes petrochemicals, cement, and manufacturing. Finally, Lan 
Gaochuan藍高川 was the founder of the Taiwan Industrial and Commercial Bank, the predecessor of the present-day First Commercial Bank.

According to Chi Zongxian, among the three main contributions made by the rise of Dadaocheng were the contributions to fiscal policy that derived from the trade in tea. This in turn fostered a network of tea-merchants and associated industries, which in turn had an enormous impact on the urbanization of the area. As the local population increased and the area became more urbanised, living standards throughout the region rose. This had a huge effect on both mortality and literacy.

The improvement of the streets in Dadaocheng represented the modernisation of Taiwan prior to the island's cession to Japan in 1895. Politically, that success was due to Liu Mingchuan's self-strengthening policies, the economic heart of which were the tea and camphor industries. The patchwork of cultural diversity that existed because of the two had an enormous impact on both local architecture and by extension the arts. In comparison, the romantic critique of capitalism in nineteenth-century Britain (and beyond) gave way to the very canvas on which keywords such as 'class,' 'culture,' and 'art' acquired their current meaning. Thus, both painting and literature began to illustrate the wider economic context.

Embedded within this environment, new forms of social class and mobility emerged. For some, the accumulated wealth and recognised status as elites were able to be transferred as privilege onto their children. Although most took over 'family businesses,' others were able to pursue more artistic careers. Growing up during Japanese rule, some of these children referred to the area 'as a piece of Europe within Taipei. ${ }^{117}$ Lin Hengdao 林衡道, once wrote that: 
There is a small stream next to Jianchang Back Street. Along the winding lane by the stream, old foreign buildings stand. I used to love walking down this narrow path as a young man and imagining whether the scenery resembled Florence in Italy $[\ldots]^{118}$

The area's 'pseudo-European' resemblance became the canvas for the first group of Taiwanese Western-style artists such as Ni Jianghui 倪蔣懷 (recognized as the first), Yang Sanlang 楊三 郎, and Lan Yinding 藍蔭鼎 (a famous watercolourist). To pass this on to the next generation of artists, they established the Research Institute of Painting (huihuayanjiusuo 繪畫研究所, funded by Ni Jianghui), an ersatz-art school in Dadaocheng. Success in business represented a rise in social mobility, and to many local merchants under the reforms initiated by Liu Mingchuan and the diversity of Dadaocheng, new forms of urban gentry were now realised.

For many in the district, modernity therefore became closely meshed with not only what they traded but also by what they ate, wore, and used. The centrality of this thus rested upon an identity built on what it meant to be a Dadaocheng resident. Unlike the residents of Deptford, there are no systematic probate records; however, what is known through personal ledgers and import records does capture the structure, hierarchy, and mobility of their community. ${ }^{119}$ Yet this was not just economic. Culturally, the area saw significant change with the establishment of the Taiwanese Cultural Association (Taiwan wenhuaxiehui臺灣文化協會) on 17 October 1921 by Chiang Weishui 蔣渭水. Because of this, Dadaocheng became the centre of Taiwanese political, cultural, and social thought and reform. ${ }^{120}$ And much of this was elite-driven. 
Tze-lan D. Sang argues that the list of 'milestones' during early parts of the twentieth century (1905 Taipei Electrical Works; 1908 Taiwan Water Purification Plant; 1915 The New Park Museum; and 1916 National Taiwan University Hospital: the largest general hospital at the time in East Asia) all culminated in the import of Western goods that included records and phonographs. In 1910 the NIPPONO Phone Co. Ltd., was established (the earliest record company in Taiwan); changing its name in 1925 to Columbia Records Co., and becoming a leading company in Taiwan until the late 1930s. Taiwanese language lyrics were subsequently set to Western-inspired dance music with Japanese and Taiwanese folk elements. Accordingly, Sang asserts that 'not only did Taiwan as periphery become a producer of new urban culture, but its export of records of Taiwanese-language popular songs to Xiamen in Fujian, China and destinations in Southeast Asia even more radically unsettled the centre-periphery distinction by putting Taipei on a synchronic plane with other centres of popular music production such as London, New York, Shanghai, and Tokyo. ${ }^{121}$

It is clear in the case of Dadaocheng that the middle classism that emerged over the course of the fin de siècle was not just defined in terms of profession. It was a combination of a number of arenas (education, consumption, the arts, etc.,) and perhaps more importantly an assertion that what they did, where they were educated, what they bought, and how they used their leisure time all contributed to a shared understanding of who they were. Dadaocheng was purposely globally situated and as a result the urban elite were able to access particular resources which they sequentially used to exercise power. Through this influence, they were able to form specific social relations that were in turn used to transmit influence and patronage. Their networking thus became critical in the bonds that existed between men who had styled themselves as gentry. Specifically, the bonds show how the 'interurban' links of marriage and 
kinship facilitated the flow of ideas and people, and therefore initiated new forms of networks. ${ }^{122}$ The alliance of marriage varied considerably and not all united equals. In certain cases, marriages often acknowledged superiority of one family over another. ${ }^{123}$ It therefore functioned as recognition of position in society.

In many ways, it was Dadaocheng and not Deptford that had more of the characteristics of a cosmopolitan neighbourhood. Like Deptford, the middle classes in Dadaocheng were housed in a predominantly poor district. In order to offset this, the urban elite established strong mutual aid associations. Endeavours to ban foot-binding, the wearing of the queue, and opium smoking were all attempted by the Japanese colonial government, but they all failed. ${ }^{124}$ Success instead was found in gentry-led aid associations. The Natural Foot Society (Tianranzuhui天然 足會), for example, was established in 1900 under the guide of Li Chunsheng and Dadaochengresident herbal doctor Huang Yujie 黃玉階. This mutual aid association was largely a response to a much larger movement (The Foot Emancipation Society, buchanzuhui不缠足會) in China. In much the same way, Lin Qingyue 林清月, in 1919, established the Hongji Hospital 宏濟醫 院 in Dadaocheng, to treat another social issue: opium addiction. ${ }^{125}$

An additional cooperative, which was similar to the Harvest Festival celebrations in churches in Deptford, was the annual ritualised belief, pudu 普渡[Universal Salvation Festival], in appeasing ghosts and the improperly dead during the seventh month of the lunar year. These 'ghosts' for the most part functioned as metaphors for the socially marginalised 
(paupers, beggars, prostitutes: the jianmin). ${ }^{126}$ As part of the ceremony, ritualistic food is offered to hungry ghosts, but subsequently consumed by the poor. ${ }^{127}$ In the late nineteenth century this was colourfully narrated by George Lesley MacKay:

The seventh month [of the lunar calendar] was the time for making offerings to all departed spirits. It was a time of great festivity and excitement $[\ldots]$ Immense quantities of food [were] offered to the spirits $[\ldots]$ When night came on and the time summoning the spirits approached [a] very unspiritual mob—-thousands and thousands of hungry beggars, tramps, blacklegs, desperadoes of all sorts, from the country towns, the city slums [...] swelled in every part of the open space, impatiently waiting their turn. [When] the spirits were satisfied, and the gong was sounded, [this] was the signal for the mob. ${ }^{128}$

Although violent cases of 'food robbery' led to Liu Mingchuan banning it in 1889, descriptions of the event elsewhere in China allude more to the hunger and alms basis of the ceremony. ${ }^{129}$ The widespread income disparity, resulting from commercialisation and the rise in the urban middle class, marshalled systematic attempts to alleviate poverty and its associated social issues. One example in the case of Taiwan was the yutingtang 育嬰堂or orphanages. Most children admitted were girls, and the largest in northern Taiwan was the renjiyuan仁濟院, which was established in 1870 by Li Chunsheng and Lian Zhendong連震東 (father of Lien Chan 連戰, a Taiwanese politician) on land donated by the Banqiao Lin family.

\section{CONCLUSION}

The two case studies presented in this paper each historically sought to avoid becoming part of the city to which they now belong. In a sense, important questions emerge: why were they 
following similar pathways? Since both locations were heavily involved in British trade, were aspects of Victorian morality and values transplanted? Was it cultural mimicry or simply an independent social construct? The middle class residents that emerged in both locations had both identified themselves locally as opposed to nationally and this was largely a result of the blanket poverty that shrouded them. This was not only in terms of the mutual aid associations that were established, but also in terms of how the poor were described and treated. How the elite accessed resources, networked, and positioned themselves on a moral high ground was cemented in their own collective desire to shape a modern urban landscape that was fitted to their own personal aspirations. The dwellers on the streets (both poor and rich) were globally situated and connected to a transnational system of social mobility and awareness: a mobility that they self-defined and interpreted. The personal fortunes and gain were enhanced by the urban elites' extended connections. To justify their new positions, the ways in which they responded to the growing wealth disparities became the markers of patronage and influence. As for the streets of nineteenth- and twentieth-century Deptford-London and DadaochengTaipei, they were not simply neutral passageways, but rather loci for work, leisure, and interaction and formed constituent arenas that represented the spirit of the local neighbourhood. And yet, these interactions were not just sudden 'outbursts' of old 'traditions,' but rather the result of an unfolding dialogue of modernities and mobility. Thus, to borrow from Cem Behar, it is through the 'bottom-up' view of place that one can view the 'real neighbourhood community that disappeared and was replaced by a more rigid administrative territorial structure. ${ }^{130}$ But change did not cease overnight and instead it has become part of the nostalgic social fabric of popular expression of regret; the 'world we have lost.' Deptford and Dadaocheng are but two average neighbourhoods in remarkably similar districts. The narrative 
that is conveyed clearly transcends notions of boundaries and identifies the fact that aspirations for social change and mobility are in fact universal.

\footnotetext{
${ }^{1}$ Morwenna Ferrier, Dalston is Dead. Long Live Deptford, Go London (23 October 2014), accessed 4 June 2019, https://www.standard.co.uk/go/london/attractions/dalston-is-deadlong-live-deptford-9811946.html

${ }^{2}$ Han Cheung, Dadaocheng, A Fascinating Neighborhood in Taipei, Taiwan Everything (17 May 2018), accessed 4 June 2019, https://taiwaneverything.cc/2018/05/17/dadaocheng/

${ }^{3}$ Corporate Watch, Tidemill: Factsheet on the Battle for Deptford, Corporate Watch (12 November 2018), accessed 4 June 2019, https://corporatewatch.org/tidemill-developmentfactsheet-on-the-battle-for-deptford/.

${ }^{4}$ Huang Chien-hao et al, Dadaocheng's Businesses Struggle with Rising Rents, Taipei Times (25 April 2015), accessed 4 June 2019, http://www.taipeitimes.com/News/taiwan/archives/2017/04/25/2003669387
}

${ }^{5}$ Gyan Prakash, Introduction, in Spaces of the Modern City, eds., Gyan Prakash and Kevin M. Kruse (Princeton, NJ: Princeton University Press, 2008), 1.

${ }^{6}$ Ibid, 2.

7 M. Woods, 'Rethinking Elites: Networks, space, and local politics,' Environment and Planning 30 (1998): 2101-2119.

${ }^{8}$ For a more indepth analytical discussion of surburban development in the 1950s, see: Richard Harris and Peter J. Larkham, Changing Surburbs Foundation, Form, and Function (New York, NY: Routledge, 1999).

${ }^{9}$ Henry F. Chorley, Sketches of a Sea-Port Town (Philadelphia, PA: E.L. Carey \& Hart, 1836), $2-3$.

${ }^{10}$ Max Weber, The City (Illinois, IL: The Free Press, 1986),66. 
11 Marcel Detienne. Comparer l'incomparable. Oserexpérimenter et construire, (Paris: Editions du Seuil, 2009); also see: Frank Muyard, 'Comparativism and Taiwan Studies: Analyzing Taiwan in/out of context, or Taiwan as an East Asian New World society,' in Comparatizing Taiwan, eds., Shu-mei Shih and Ping-hui Liao (London: Routledge, 2015), 1314.

${ }^{12}$ Joseph Bullman et al, The Secret History of Our Streets: A story of London (London: BBC Books, 2013), 79.

${ }^{13}$ G.F. Bosworth, Kent (Cambridge: Cambridge University Press, 1909), 31; Judith Flanders, The Victorian City: Everyday Life in Dickens' London (London: Atlantic Books, 2012), 201; and Philip L. Gibbard, Pleistocene History of the Lower Thames Valley (Cambridge: University of Cambridge Press, 1994), 102.

${ }^{14}$ Alp Yücel Kaya, In the Hinterland of Izmir: Mid-nineteenth century traders facing a new type of fiscal practice, in Merchants in the Ottoman Empire, eds. SuraiyaFaroqhi and Gilles Veinstein (Paris: Peeters, 2008), 264; and Thomas B. Gold, State and Society in the Taiwan Miracle (Armonk, NY: M.E. Sharpe, Inc., 1986), 26-27.

${ }^{15}$ İsmail HakkiKadi, Ottoman and Dutch Merchants in the Eighteenth Century: Competition and cooperation in Ankara, Izmir, and Amsterdam (Leiden: BRILL, 2012), 170-71.

${ }^{16}$ William T. Rowe, Hankow: Conflict and community in a Chinese city, 1796-1895 (Stanford, CA: Stanford University Press, 1989), 3.

${ }^{17}$ S.N. Eisenstadt, 'Multiple Modernities,' Daedalus, 129:1 (2000): 3.

${ }^{18}$ Kenneth McPherson, 'Port Cities as Nodal Points of Change: The Indian Ocean, 1890s1920s,' in Modernity \& Culture: From the Mediterranean to the Indian Ocean, eds. Leila Tarazi Fawaz and C.A. Bayly (New York, NY: Columbia University Press, 2002), 75. 
${ }^{19}$ Ibid, 75.

${ }^{20}$ John Darwin, After Tamerlane: The rise \& fall of global empires, 1400-2000 (London: Penguin Group, 2008), 14.

${ }^{21}$ Ibid, 54.

${ }^{22}$ Margaret R. Hunt, The Middling Sort: Commerce, gender, and family in England, 1680-1780 (Oakland, CA: University of California Press, 1996)

${ }^{23}$ Mark Elvin, 'The Administration of Shanghai,' in The Chinese City Between Two Worlds, eds., Mark Elvin and G. William Skinner (Stanford, CA: Stanford University Press, 1974), $240-41$.

${ }^{24}$ Vivienne Richmond, Clothing the Poor in Nineteenth-Century England (Cambridge: CUP, 2013), 8.

${ }^{25}$ Eric Hobsbawm, The Age of Capital 1848-1875 (London: Wiedenfield\& Nicolson, 1995), 219-20.

${ }^{26} \mathrm{Ch}$ ü (1962), 170.

${ }^{27}$ See: Mark McNicholas, Scamming the Purchase-of-Rank System in Qing China, Late Imperial China 34:1 (2013): 108-136.

${ }^{28}$ Woods (1998), 2108.

${ }^{29}$ Penelope Corfield, Business Leaders and Town Gentry in Early Industrial Britain: Specialist occupations and shared urbanism, Urban History 39:1 (2012): 28.

${ }^{30}$ Colin Pooley and Sian Pooley refer to this development of new space as being akin to 'suburban growth'. Pooley, Colin G. and Sian Pooley, Constructing a Suburban Identity: Youth, femininity and modernity in late-Victorian Merseyside, Journal of Historical Geography 26 (2010): 402-410.

${ }^{31}$ Jess Steele, Turning the Tide: The history of everyday Deptford from the Romans to the present (London: Deptford Forum Publishing Ltd., 1993), 1. 
${ }^{32}$ Roy Porter, London: A social history (London: Penguin Books, 2000), 122-23, 269; Gillian Tindall, The House by the Thames and the People Who Lived There (London: Pimlico, 2007), 94.

${ }^{33}$ Porter (2000), 269.

${ }^{34}$ Ibid, 269.

${ }^{35}$ Charles Dickens, Oliver Twist (London; Richard Bentley, 1837; republished Penguin Books, London, 2003), 416-17.

${ }^{36}$ Journals of the House of Lords, 27 March 1801.

${ }^{37}$ Tindall (2007), 9.

${ }^{38}$ Steele (1993), 62.

${ }^{39}$ James W. Davidson, The Island of Formosa, Past and Present (London: Macmillan \& Company, 1903), 175-6.

${ }^{40}$ Ibid, 75.

${ }^{41}$ See: Charles Booth Online Archive, http://booth.lse.ac.uk/cgi-

bin/do.pl?sub=view_booth_and_barth\&args=531000,180400,6,1arge,5, accessed 4 April, 2016.

${ }^{42}$ UK census data for Deptford, 1891.

${ }^{43}$ Jess Steele (ed.) The Streets of London: The Booth notebooks - South East (London: Deptford Forum Publishing Ltd., 1997), 135-37.

${ }^{44}$ UK census data for Deptford, 1891.

${ }^{45}$ Steele (1997), 137-139.

${ }^{46}$ Ibid, 137.

${ }^{47}$ UK census data for Deptford, 1891. Schedule 358. 
${ }^{48}$ See, Niki J.P. Alsford, Transitions to Modernity: The Spirit of 1895 and the Cession of

Formosa to Japan (London: Routledge, 2017),140-41.

${ }^{49}$ UK census data for Deptford, 1891.

${ }^{50}$ Ibid.

${ }^{51}$ Ackroyd (2007), 190.

${ }^{52}$ George L. MacKay, MacKay’s Diaries: Original English Version, 1871-1901 (Taipei,

Taiwan: Aletheia University, 2007), 16.

${ }^{53}$ UK census data for Deptford, 1891.

${ }^{54}$ Steele (1993), 43.

${ }^{55}$ Ibid, 96.

${ }^{56}$ Gerry Holloway, Women and Work in Britain since 1840 (London: Routledge, 2005), 16.

${ }^{57}$ Hilda Kean, Animal Rights; Political and social change in Britain since 1800 (London:

Reaktion Books, 1998), 132.

${ }^{58}$ Chen Huiwen 陳惠雯, Dadaocheng chamorenditu, 大稻埕查某人地圖 [Women's Map of Dadaocheng], (Taipei: Boyyoung Press, 1999), 121. Pamela Cox and Annabel Hobley, Shopgirls (London: Hutchinson, 2014), 12-14.

${ }^{59}$ Chen Huiwen (1999), 121.

${ }^{60}$ Cox and Hobley (2014), 3-4.

${ }^{61}$ Weng Sheng-feng 翁聖峰, Rishi shiqizhiyefunuticaiwenxu de bianqianjinuxingdiwei, 日治 時期職業婦女題材文學的變遷及女性地位[Changes in Women's Status and Literary Representation of Working Women in the Japanese Colonial Period]. MonumentaTaiwanical (2010): 1-31. 
${ }^{62}$ Andrew Tarrant, 'The Deptford Fund and the Albany Institute: Aspects of Philanthropy in a Working-Class Area, 1919-1939,' Unpublished MA Diss., St John's College, Oxford (n.d.), $10-11$.

${ }^{63}$ Ibid, 13.

${ }^{64}$ Bobby Woodruff, 'The Deptford Fund, 1894-1980,' (unpublished manuscript) held at Lewisham Local History and Archives Centre (87/8143).

${ }^{65}$ Steele (1993), 146.

${ }^{66}$ Anges L. Money, The History of The Girls' Friendly Society (London: Wells Gardner, Darton\& Co., ltd., 1911).

${ }^{67}$ Geoffrey Crossick, An Artisan Elite in Victorian Society: Kentish London, 1840-1880

(London: Rowman and Littlefield, 1978), 210.

${ }^{68}$ Steele (1993), 127.

${ }^{69}$ Crossick, 200.

${ }^{70}$ Sarah Milan, 'Refracting the Gaselier: Understanding Victorian responses to domestic gas lighting,' in Domestic Space; Reading the nineteenth-century interior, eds., Inga Bryden and Janet Floyd (Manchester: MUP, 1999), 99.

${ }^{71}$ Anon, 'The Development of Deptford 1870-1895,' (unpublished thesis, Lewisham: Archives \& Local History Department, n/a), 62.

${ }^{72}$ Ibid, 64.

${ }^{73}$ Ibid, 64.

${ }^{74}$ Alec Ellis, A History of Children's Reading and Literature (Oxford: Pergamon Press, 2014), 83. 
${ }^{75}$ The boarding schools were situated on Clyde Street, Duke Street, Grove Street, Hughes Fields, Stanley Street, Regent Street, and Creek Road.

${ }^{76}$ Neil Rhind, Richard Wheen, Greenwich Industrial Historical Society Journal (Dec, 1998); and Deptford Borough Council, The Metropolitan Borough of Deptford: Official Guide, 193536 (London: Ed. J. Burrow \& Co. Ltd., 1936).

${ }^{77}$ UK census data for Deptford, 1891.

${ }^{78}$ Charles Booth, Life and Labour of the People in London: Poverty volume 2 (London: Macmillan and Co., Ltd., 1904), 53-54; and Anon, 'The Development of Deptford into an Industrial Suburb of London,' (unpublished manuscript, Lewisham: Archives \& Local History Department).

${ }^{79}$ Lewisham Archives, 'Deptford Soup Institution,' (5 December, 1831), A70/20/1.

80 Wang Shiqing 王世慶. Qingdai Taiwan shehuijingji清代臺灣社會經濟 [The Social Economy of Taiwan during the Qing Period]. (Taipei: Linking Books, 1994).

${ }^{81}$ Lewisham Archives, 'Deptford Soup Institution,' (5 December, 1831), A70/20/1.

${ }^{82}$ For a background reading on Taiwan history, I suggest: Murray Rubinstein (ed.), Taiwan: A new history (Armonk, NY: M.E. Sharpe, 1999).

${ }^{83}$ Shepherd (1995), 170.

${ }^{84}$ Ronald G. Knapp, 'Settlement and Frontier Land Tenure,' in China's Island Frontier: Studies in the historical geography of Taiwan, ed. Ronald G. Knapp (Taipei: SMC Publishing Inc., 1980), 60.

${ }^{85}$ Mark A. Allee, Law and Local Society in Late Imperial China: Northern Taiwan in the nineteenth century (Taipei: SMC Publishing Inc., 1994), 16. 
${ }^{86}$ Henry Shih-shan Tsai, Maritime Taiwan (Armonk, NY: M.E. Sharpe, 2009), 9.

${ }^{87}$ Ibid, 9.

${ }^{88}$ Lin, Yu-ju, Qingdaitaiwangangkou de kongjianjiegou, 清代臺灣港口的空間結構 [The

Spatial Structure of the Ports in Taiwan During the Qing Dynasty]. (Taipei: Zhishufang, 1995).

${ }^{89}$ Chen Chiukun, 'From Landlords to Local Strongmen: The transformation of local elites in mid-Ch'ing Taiwan, 1780-1862,' in Taiwan: A new history, ed. Murray Rubinstein (Armonk, NY: M.E. Sharpe, 1999), 147.

${ }^{90}$ Robert Gardella, 'From Treaty Ports to Provincial Status,' in Taiwan: A new history, ed. Murray Rubinstein (Armonk, NY: M.E. Sharpe, 1999), 178-79

${ }^{91}$ Lin Man-houng, 'Maoyiyuqingmo Taiwan de jingjishehuibianqian, 1860-1895 貿易與清末 台灣的經濟社會變遷, 1860-1895,' [Trade, Economic, and Social Change in Late Qing Taiwan] ShihuoYuekan 9:4 (1979): 18-31.

${ }^{92}$ Ibid, 5; and P.D. Coates, The China Consuls: British Consular Officers 1843-1943 (Oxford: Oxford University Press, 1988), 319.

${ }^{93}$ Dadaocheng from 'dao 稻' meaning rice and 'da cheng 大埕'meaning an empty space or courtyard. In the Taiwanese (or Southern Min) vernacular this is Romanized as Tōa-tiū-tia $\hat{a}^{n}$ or Twatutia. During the Japanese colonial period this was Romanized as Daitotei.

${ }^{94}$ Gardella (1999), 178.

95 The Committee of the Formosan Special Census Investigation, The Special Population Census of Formosa, 1905 (Tokyo: Imperial Printing Bureau, 1909).

${ }^{96}$ Steele (1993), 76. 
${ }^{97}$ Hong Tengyun 洪騰雲 owned most of the land between present-day Guanqian Road 館前 路 to the East Wall, see: Hechutushe河出圖社,GudituTaibeisanbu: yibajiuwuqingdaitaibeigucheng 古地圖台北散步:一八九五清代台北古城 [Walking the Antique Maps of Taipei: The Qing Period to 1895] (Taipei: GuoshiChubanshe, 2004), 29, 49. 98 Huang Hsin-ying, "A Study of the "Foreign Settlements" in Taiwan during Japanese Governance,' (MA diss., Chung Yuan University, Department of Architecture, 2002), 32.

${ }^{99}$ A good example of this is the land agreement registered to the British consulate in Tamsui, see: FO 678/3051.

${ }^{100}$ Leonard H. Gordon, Confrontation over Taiwan: Nineteenth-century China and the Powers (Plymouth: Lexington Books, 2009), 98; Niki J.P. Alsford, Transitions to Modernity: The spirit of 1895 and the cession of Formosa to Japan (London: Routledge, 2018),142.

${ }^{101}$ See diary of John Dodd, Niki J.P. Alsford, The Witnessed Account of British Resident John Dodd at Tamsui (Taipei: SMC Publishing Inc., 2010).

102 Chi Zongxian, 池宗憲, Taibeishidatongquguidejieshi, 台北市大同區貴德街史 [The History of Guide Street, Datong District, Taipei City], (Taipei: Taipei City Archives, 2003), 8. ${ }^{103}$ Porter (2000), 250.

${ }^{104}$ Steele (1993), 76.

${ }^{105}$ Alsford (2018), 193.

${ }^{106}$ Gardella (1999), 187. 
107 William M. Speidel, 'The Administrative and Fiscal Reforms of Liu Ming-Ch'uan in Taiwan, 1884-1891: Foundation for self-strengthening,' The Journal of Asian Studies 35:3 (1976): 447.

${ }^{108}$ Gardella (1999), 189.

${ }^{109}$ Ibid, 189.

${ }^{110}$ Speidel (1976), 442.

${ }^{111}$ Chi (2003), 10.

${ }^{112}$ Faragó (1997), 715.

${ }^{113}$ Fu-san Huang, 'Shijiushijizhiwailaitiaozhanyu Taiwan xinshangye, 十九世紀之外來挑戰

與臺灣新商業,' [The New Business and Foreign Challenge of the $19^{\text {th }}$ Century Taiwan],

Historical Monthly 201 (2004): 60-73.

${ }^{114}$ Ibid, 60-73; and Norio Tamaki, Japanese Banking: A history, 1859-1959 (Cambridge:

Cambridge University Press, 1995), 101.

${ }^{115}$ Chi (2003), 21.

${ }^{116}$ W.D. Rubinstein, Elites and the Wealthy in Modern British History: Essays in Social and Economic History (Brighton: Harvester, 1981)

117 Ibid, 61-63.

${ }^{118}$ Ibid, 63.

${ }^{119}$ Probate records in Taiwan tend not to list material items (unless they are of particular value, such as heirlooms). Rather they allude to the distribution of the deceased's wealth. For example, the Last Will and Testimony of Li Chungsheng, records a total wealth of 827, 300 Yen). 9,000 is donated to churches in Taipei, Japan, and Xiamen (each receiving 3,000). 35 per 
cent to be left to his "hard-working and responsible" eldest son (Li Jingsheng 李景盛), 25 per cent to his “rather lazy and not much of an achiever” second son (Li Gaosheng 李高盛), with 30 per cent going to his third son who was “quite a responsible person” (Li Tiansheng 李添 盛). Finally 10 per cent went to his grandson Li Yanling 李延齡 (the eldest son of Li Jingsheng), ITH, Li Chunsheng's Will and Testament (16 May大正 20).

${ }^{120}$ Jiang Chaogen 蔣朝根, Jiangweishuiliuzhenji蔣渭水留真集[Photographic Collection of Chiang Wei-shui] (Taipei: Taipei city Archive, 2006), 43-46.

${ }^{121}$ Tze-lan D. Sang, 'Reclaiming Taiwan's Colonial Modernity: The case of Viva Tonal: The dance age,' in Documenting Taiwan on Film: Issues and methods in new documentaries, eds., Sylvia Li-chun Lin and Tze-lan D. Sang (London: Routledge, 2012), 71-72.

${ }^{122}$ G. William Skinner, 'Cities and the Hierarchies of Local Systems,' in The City in Late Imperial China ed., G. William Skinner (California, CA: Stanford University Press, 1977), 276.

${ }^{123}$ This tended to follow the groom's side, see: Muhammad Amir Ahmad Khan, 'Local Nodes of a Transnational Network: A case study of a Shi'i family in Awadh, 1900-1950,' Journal of the Royal Asiatic Society 24:3 (2014): 401. In Taiwan the opposite was also evident. A noted example is the marriage of Du Congming 杜聰明 to Lin Shuangsui 林雙隨 from the Wufeng Lin family. Although Du did not necessarily 'marry in,' it was agreed due to his achievements as a doctor. His position within society was further elevated in the marriage of his daughter, 
Du Shushun 杜淑純to Lin Hengdao 林衡道 from the Banqiao Lin family. A noteworthy example of 'marrying in' is OuJiangchuang 歐劍窗 (Chen Ouyang Teng 陳歐陽藤), who was a poet and traditional herbalist. His father Ou Yang 歐陽 married into the Chen family in Dadaocheng, see: Lin Weizhou 林偉洲 et al, Taiwan lishirenwuxiaozhuan: minqingjirijushiqi, 臺灣歷史人物小傳:明清暨日據時期 [Biography of Historical Figures of Taiwan: Ming Dynasty, Qing Dynasty and the Japanese Period] (Taipei: National Central Library, 2003), 689. ${ }^{124}$ Hui-yu Caroline Tsai, Taiwan in Japan's Empire Building (London: Routledge, 2009), 128. 125 The hospital was later converted to The Taipei Rehabilitation Bureau (TaibeiGengshengyuan 台北更生), see Anon, Taiwan yiliaosibainian, 台灣醫療四百年 [The Four-Hundred Years of Medical Development in Taiwan]. Taipei: Rhythms Monthly, 2006), $130-31$.

${ }^{126}$ Robert P. Weller, 'Bandits, Beggars, and Ghosts,' American Ethnologist 12:1 (1985), 46.

${ }^{127} \mathrm{Wu}$ Yingtao 吳瀛濤, Taiwan minsu, 臺灣民俗 [Taiwan Folkways] (Taipei: Jong Wen Books Co., 1980), 24.

${ }^{128}$ George Lesley MacKay, From Far Formosa (London: Oliphant Anderson and Ferrier, 1896), 130.

${ }^{129}$ Weller (1985), 50.

${ }^{130}$ Cem Behar, A Neighborhood in Ottoman Istanbul (New York, NY: State University Press, 2003), 181. 